\title{
Combined Mutagenesis in Soybean (Glycine max L.)
}

\author{
A.M. Mahalle ${ }^{1 *}$, M.N. Mishra ${ }^{2}$, N.J. Chikhale ${ }^{3}$ and S.K. Burghate ${ }^{4}$ \\ ${ }^{1}$ Gram Sevak Training Center, Amravati-444603 (MS), India \\ ${ }^{2}$ Department of Plant Breeding and Genetics, R.B.S. College, Bichpuri, Agra (UP), India \\ ${ }^{3}$ Shri Shivaji Agriculture College, Amravati-444603 (MS), India \\ ${ }^{4}$ Department of Agriculture Botany, Dr. PDKV, Akola 444104 (MS), India \\ *Corresponding author
}

A B S T R A C T

\begin{tabular}{|l|}
\hline Ke y w or d s \\
Mutagens, Soybean, JS- \\
335, Gamma rays, EMS \\
\hline Article Info \\
\hline Accepted: \\
16 April 2018 \\
Available Online: \\
10 May 2018 \\
\hline
\end{tabular}

Keywords

\section{Introduction}

Soybean is the major oilseed crop accounting for $30 \%$ of the oilseeds area and Madhya Pradesh, Maharashtra, and Rajasthan together contribute about 97 and 96 percent of total area and production of soybean in the country respectively. It is an important food, feed and principle oilseed which is cultivated on a large scale throughout the world. Recently, soybean has been gaining importance as a food crop, due to its content of digestive protein, vitamins, minerals and phytosterols. Combined mutagenesis offer several advantages over the sole physical and chemical mutagens. Since chance of structural alteration of chromosome and the resulting genetic deleterious consequences are less. Soybean is predominantly a self-pollinated crop species with limited genetic variation for both qualitative and quantitative traits. Mutagenesis offers an excellent scope for increasing the spectrum of variation (Mouli et al., 1989).

\section{Materials and Methods}

Air dried, well filled and uniform seeds of JS335 variety of Soybean were obtained from the Senior Research Scientist (Oilseeds) Dr. Panjabrao Deshmukh Krishi Vidyapeeth, Akola for physical mutagenic treatment, these seeds were treated with 150, 250 and $350 \mathrm{~Gy}$ gamma rays $\left({ }^{60} \mathrm{CO}\right.$ Source). For chemical 
mutagenic treatment, the seeds were presoaked in water for $6 \mathrm{hrs}$, followed by immersing separately in 0.05 per cent, 0.1 per cent and 0.2 per cent aqueous solution of ethyl methane sulphonate for 6 hrs. For combination treatment the seed irradiated with 150, 250 and 350 Gy gamma rays were immersed in 0.2 percent, 0.1 per cent and 0.05 per cent ethyl methane sulphonate respectively, after presoaking in distilled water for $6 \mathrm{hrs}$ followed by washing of treated seed under running water for $2 \mathrm{hrs}$. The treated seeds were sown in augmented block design along with dry and presoaked control in $\mathbf{M}_{1}$ generation during kharif 2008 (Table 1). During $\mathrm{M}_{1}$ generation the observations were recorded on germination both in laboratory and field conditions, root length, shoot length, pollen sterility, days to 50 per cent flowering and mortality.

\section{Results and Discussion}

Germination in M1 generation was found to be reduced as the dose or concentration of mutagen increased. However, the germination was found lowest in combined treatment of gamma rays + EMS followed by sole treatment of EMS and gamma rays. In general maximum reduction in germination (42.69 and 22.10 per cent in field) in higher dose of 300 Gy gamma rays +0.05 per cent EMS. The seed germination decreased with increased in the dose or concentration of mutagen (Singh et al., 1988). Thombre et al., (1981) also reported delayed and reduced germination percentage in pigeonpea. This reduction might be due to disturbance caused at physiological level of cell or acute chromosomal change or combined effect of both (Sinha and Godward, 1973). The dose dependent decrease in field germination was also noted under field condition by Nandanwar and khamankar (1996) in mug bean and Nadarajan et al., (1985) in pigeonpea. This reduction might be due to disturbance caused at physiological level of cell or acute chromosomal change or combined effect of both (Sinha and Godward, 1973). The progressive decrease in seedling growth with corresponding increase in doses or concentrations of the mutagens was observed.

Maximum decreased in both root length (8.41 $\mathrm{cm})$ and shoot length $(7.02 \mathrm{~cm})$ was observed in combined treatment of $300 \mathrm{~Gy}$ gamma rays +0.05 per cent EMS. The findings of similar nature were also reported by Vi et al., (1992) in crown vetch. Mutagenic sensitivity can be attributed to the level of differentiation of rudimentary plant parts at the time of treatment on one hand and the extent of damage to the growth components like rate of cell division, cell elongation and various hormones and biosynthetic pathways related to growth and development on the other. Scholz and Lehmann (1964) regarded inflected disturbance in growth to be due to enzymatic activity. The response of doses of various mutagens measured on the basis of seedling growth has been demonstrated in Cereck et al., (1971). Similar results were also reported by Singh et al., (1997) and Wakode et al., (2000).

The pollen sterility was found increased in all the treatment of gamma rays, ethyl methane sulphonate and their combinations as compared to their respective control. Similar results were found by Chandrashekhar et al., (1997). The treatment of 300 Gy gamma rays showed increased pollen sterility (28.85 percent). The results obtained are in conformity with those of Upadhyaya et al., (1984) in soybean. This sterility induced by different mutagens is presumably due to chromosomal aberrations and damage or meiotic irregularities, which resulted in the formation of abnormal pollen. Reduced pollen fertility due to various mutagenic treatments is also one of the parameters to assess the mutagenic effectiveness and efficiency (Naik and Nadaf, 1997). 
Int.J.Curr.Microbiol.App.Sci (2018) 7(5): 1777-1780

Table.1 Treatment details

\begin{tabular}{|c|c|}
\hline Treatment code & Treatment details \\
\hline \multicolumn{2}{|l|}{ Gamma rays } \\
\hline $\mathrm{T}_{1}-150 \mathrm{gy}$ & Irradiation of seeds with 150 Gy Gamma-rays \\
\hline $\mathrm{T}_{2}-250 \mathrm{gy}$ & Irradiation of seeds with 250 Gy Gamma-rays \\
\hline $\mathrm{T}_{3}-300 \mathrm{gy}$ & Irradiation of seeds with 300 Gy Gamma-rays \\
\hline \multicolumn{2}{|l|}{ EMS } \\
\hline $\mathrm{T}_{4}-0.05 \%$ EMS & Presoaking of seeds for $6 \mathrm{hrs}$. followed by $6 \mathrm{hr}$.soaking in $0.05 \%$ EMS \\
\hline $\mathrm{T}_{5}-0.1 \%$ EMS & Presoaking of seeds for $6 \mathrm{hrs}$. followed by $6 \mathrm{hr}$. soaking in $0.1 \%$ EMS \\
\hline $\mathrm{T}_{6}-0.2 \% \mathrm{EMS}$ & Presoaking of seeds for 6 hrs. followed by 6 hrs. soaking in $0.2 \%$ EMS \\
\hline \multicolumn{2}{|l|}{ Combinations } \\
\hline $\begin{array}{l}\mathrm{T}_{7}-150 \mathrm{~Gy}+0.2 \% \\
\mathrm{EMS}\end{array}$ & $\begin{array}{l}\text { Irradiation of seeds with } 150 \mathrm{~Gy} \text {, presoaking for } 6 \text { hrs followed by } 6 \mathrm{hrs} \text {. } \\
\text { soaking in } 0.2 \% \text { EMS }\end{array}$ \\
\hline $\begin{array}{l}\mathrm{T}_{8}-250 \mathrm{~Gy}+0.1 \% \\
\text { EMS }\end{array}$ & $\begin{array}{l}\text { Irradiation of seeds with } 250 \mathrm{~Gy} \text {, presoaking for } 6 \mathrm{hrs} \text { followed by } 6 \mathrm{hrs} \text {. } \\
\text { soaking in } 0.1 \% \mathrm{EMS}\end{array}$ \\
\hline $\begin{array}{l}\mathrm{T}_{9}-300 \mathrm{~Gy}+ \\
0.05 \% \mathrm{EMS}\end{array}$ & $\begin{array}{l}\text { Irradiation of seeds with } 300 \mathrm{~Gy} \text {, presoaking for } 6 \mathrm{hrs} \text { followed by } 6 \mathrm{hr} \text {. } \\
\text { soaking in } 0.05 \% \text { EMS }\end{array}$ \\
\hline \multicolumn{2}{|r|}{ o } \\
\hline $\mathrm{T}_{10}-$ Dry & Control (Dry seeds) \\
\hline $\mathrm{T}_{11}-$ Presoaked & Control (Seeds presoaked in distilled water only) \\
\hline
\end{tabular}

Table.2 Mean performance of the parameters under study as influenced by different mutagenic treatments in $\mathrm{M}_{1}$ generation

\begin{tabular}{|c|c|c|c|c|c|c|c|}
\hline \multirow[t]{2}{*}{ Treatments } & \multicolumn{2}{|c|}{ Germination (\%) } & \multicolumn{2}{|c|}{ Seedling growth } & \multirow{2}{*}{$\begin{array}{c}\text { Pollen } \\
\text { sterility } \\
(\%)\end{array}$} & \multirow{2}{*}{$\begin{array}{c}\text { Days to } 50 \\
\text { percent } \\
\text { flowering }\end{array}$} & \multirow{2}{*}{$\begin{array}{c}\text { Mortalits } \\
(\%)\end{array}$} \\
\hline & Lab. & Field & $\begin{array}{l}\text { Root } \\
\text { length } \\
\text { (cm) }\end{array}$ & $\begin{array}{c}\text { Shoot } \\
\text { length } \\
(\mathrm{cm})\end{array}$ & & & \\
\hline \multicolumn{8}{|l|}{ Gamma rays } \\
\hline T1-150Gy & 74.21 & 62.45 & 12.69 & 11.30 & 16.33 & 41.36 & 27.80 \\
\hline T2 - 250Gy & 70.58 & 58.41 & 10.33 & 9.50 & 22.56 & 40.28 & 34.52 \\
\hline T3-300Gy & 60.21 & 40.77 & 9.35 & 8.41 & 28.85 & 48.79 & 48.70 \\
\hline \multicolumn{8}{|l|}{ EMS } \\
\hline T4-0.05\% EMS & 77.65 & 63.49 & 12.97 & 10.50 & 14.22 & 42.56 & 24.36 \\
\hline T5 - 0.1\% EMS & 76.50 & 59.87 & 12.00 & 9.40 & 15.26 & 41.54 & 30.40 \\
\hline T6-0.2\% EMS & 69.45 & 54.12 & 10.23 & 9.00 & 18.39 & 40.88 & 42.36 \\
\hline \multicolumn{8}{|l|}{ Combination } \\
\hline T7 - 150 Gy + 0.2\% EMS & 53.36 & 46.90 & 11.25 & 9.33 & 24.66 & 43.65 & 38.41 \\
\hline T8- 250 Gy + 0.1\% EMS & 49.87 & 31.87 & 9.56 & 8.21 & 28.00 & 48.75 & 45.62 \\
\hline T9-300 Gy + 0.05\% EMS & 42.69 & 22.10 & 8.41 & 7.02 & 26.58 & 40.00 & 55.68 \\
\hline \multicolumn{8}{|l|}{ Control } \\
\hline T10-Dry & 91.56 & 85.67 & 13.96 & 12.54 & 5.26 & 41.89 & 5.50 \\
\hline T11- Presoaked & 92.00 & 86.99 & 13.54 & 11.94 & 6.38 & 42.97 & 5.69 \\
\hline
\end{tabular}


Days to 50 per cent flowering was found higher in sole treatment of 300 Gy gamma rays and in some higher and combined doses of gamma rays and EMS sole.

The effect of gamma rays consequent upon an increased in its unit dose in combination with either colchicines or EMS like shifted the mean values to correspondingly higher level (Singh, 1988b). Rajput (1974) stated that the delay in flowering might be due to prolong and persistent vegetative growth that must have consumed more time for mitotic arrest in flowering primordia.

Delay in flowering due to Xrays treatment was also recorded by Patil (1972) in groundnut. This character might be primary controlled by major genes whose expression was affected either by 'modifiers' or complementation and hence more delayed flowering was occurred (Johnson et al., 1966).

The seedling mortality was found to be very high in higher doses of the mutagens. The mortality was observed highest (55.68 per cent) in combined treatment of 300 Gy gamma rays + 0.05 per cent EMS followed by that in sole treatment of 300 Gy gamma rays and in combined treatment of 300 Gy gamma rays + 0.05 per cent EMS (Table 2). Similar results were reported by Raut et al., (1982).

The results of mortality obtained in the present case are in the line of work of Paliwal and Kumar (1971) in pea and spices and Singh et al., (1988) in groundnut. Increased mortality in treated population could be due to the series of events occurring at the cellular level which affect the vital micro-molecules resulting in physiological imbalance (Bacq and Alexander, 1961 and Conger et al., 1976). It could be due to an inhibition of the synthesis of auxin as suggested by Gorden and Webber (1958). The reduction in plant survival was generally the result of delay in and or inhibit the of physiological and biochemical process necessary for survival and the changes in balanced production of regulators (Meherchandani, 1975).

The mortality percentage could be attributed to chromosome abnormalities causing reduced fertility or physiological disturbances. Random modification in DNA will certainly change the function of gene or the number of genes resulting significant heritable changes. Though mutations are generally recessive in nature and are harmful/lethal to the organism, Mutant can be dominant as well. Hence the effect are normally perceived until the second generation of the treatment (Tah, 2006)

\section{References}

Nadarajan, N.; R.S. Ramlingam; N. Sivasamy (1985): Biological effect of mutagenic treatment in Cajanus cajan L. Millsp. Madras Agric. J. 72(6): 301-305.

Nandanwar, R.S. and Y.G. Khamankar (1996): Induced variability for quantitative characters in mung bean [Vigna radiata L. Wilczek] in MI generation. In: Proc. of seminar on strategies for increasing pulses production in Maharashtra, 7-8 March 1996 at PDKV Akola.

Singh, A.B.; Singh, O.B. and Shrivastava, A.N., 1988. Recurrent radiation in groundnut (Arachis hypogaea L.) Farm Sci. J., 3(1): 60-65.

Sinha, S.S.N. and M.B.H. Godward (1972): Radiation studies in Lens culinaris. Ind. J. Genet. 32(3): 331-339.

Thombre, P.G., V.S. Shinde and LA. Madrap (1981): Radio sensitivity in red gram. Pulse Crop News I. Pp. 1:4.

\section{How to cite this article:}

Mahalle, A.M., M.N. Mishra, N.J. Chikhale and Burghate, S.K. 2018. Combined Mutagenesis in Soybean (Glycine max L.). Int.J.Curr.Microbiol.App.Sci. 7(05): 1777-1780.

doi: https://doi.org/10.20546/ijcmas.2018.705.207 